\author{
ROMAN WRÓBLEWSKI \\ ORCID: 0000-0003-0142-9274 \\ Uniwersytet Wrocławski \\ Wydział Filologiczny, Instytut Dziennikarstwa i Komunikacji Społecznej
}

\title{
Medialny obraz pielgrzymek Jana Pawła II do Polski w latach osiemdziesiątych ubiegłego wieku na łamach „Tygodnika Mazowsze”
}

\begin{abstract}
Abstrakt
W artykule przedstawiono rekonstrukcję obrazu medialnego dwóch pielgrzymek Jana Pawła II do Polski w latach osiemdziesiątych XX wieku. Materiałem były teksty z „Tygodnika Mazowsze”, jednego z najważniejszych czasopism drugiego obiegu wydawniczego. Jako metodę wybrano analizę zawartości czasopism. Pozwoliła ona na określenie różnic $\mathrm{w}$ opisach obu wizyt. Na podstawie kategoryzacji tematycznej udało się wskazać, że na obraz medialny pielgrzymek papieskich w „Tygodniku Mazowsze” wpływa głównie kontekst społeczno-polityczny. Opisy pielgrzymek są elementem czarno-białego obrazu świata.
\end{abstract}

Słowa kluczowe: pielgrzymka, Jan Paweł II, prasa podziemna, „Tygodnik Mazowsze”, analiza zawartości.

Celem niniejszego artykułu jest próba rekonstrukcji obrazu pielgrzymek Jana $\mathrm{Pa}$ wła II jako wielowymiarowego wydarzenia medialnego w jednym z największych czasopism drugiego obiegu wydawniczego lat osiemdziesiątych ubiegłego wieku, jakim był „Tygodnik Mazowsze”. O znaczeniu tego wydawnictwa świadczą wysoki nakład i kolportaż na terenie całego kraju. Mogło więc szeroko docierać ze swoim przekazem. Wydaje się ono także ważne dla historii mediów, ponieważ to właśnie zespół „Tygodnika Mazowsze” w całości tworzył „Gazetę Wyborczą”, czyli jeden z istotnych tytułów współczesnego rynku medialnego w Polsce.

Temat drugiej i trzeciej pielgrzymki papieskiej już wcześniej pojawiał się w analizach naukowych, w których przedstawiano reakcję podziemnych struktur „Solidarności” oraz opozycji politycznej, a także opinie z prasy podziemnej (Majchrzak 
2014; Majchrzak 2019; Łabędź 2019). Jednak wydaje się, że wyjątkowa pozycja „Tygodnika Mazowsze" wśród czasopism nielegalnie wydawanych w latach osiemdziesiątych ubiegłego wieku skłania do szczególnego przedstawienia obrazu pielgrzymek właśnie w tym tytule.

Badanie zostało przeprowadzone z wykorzystaniem analizy zawartości, która jest:

zespołem różnych technik systematycznego badania strumieni lub zbiorów przekazów, polegającego na możliwie obiektywnym (w praktyce zwykle intersubiektywnym zgodnym) wyróżnianiu i identyfikowaniu ich możliwie jednoznacznie skonkretyzowanych, formalnych lub treściowych, elementów oraz na możliwie precyzyjnym (w praktyce: ilościowym) szacowaniu rozkładu występowania tych elementów i na głównie porównawczym wnioskowaniu, a zmierzającego przez poznanie zawartości przekazów do poznania in nych elementów i uwarunkowań procesu komunikacyjnego. (Pisarek 1983: 45)

Analiza zawartości pozwala na badanie zbiorów przekazów. W tym konkretnym przypadku był to zamknięty zbiór tekstów, które ukazały się w jednym tytule prasowym i nawiązywały do jednego tematu. Opis opierał się na kategoryzacji tematycznej — na jej podstawie można było określić tendencje w opisach obu pielgrzymek w „Tygodniku Mazowsze”.

\section{Pielgrzymka — wieloznaczność, wielowymiarowość}

Pielgrzymka w Słowniku języka polskiego pod redakcją Witolda Doroszewskiego jest definiowana jako 'wędrówka w celu uczczenia kogo lub czego, w szczególności wędrówka do miejsc kultu (dawniej także: podróż)' lub 'grupa pielgrzymów wędrujących razem w celu uczczenia miejsc kultu' (www1). Podobne znaczenia podaje także Mieczysław Szymczak (Szymczak 1995: 623). Samo słowo jest pochodzenia łacińskiego: od peregrinatio, co oznacza 'pobyt poza krajem, wędrówkę, podróż' (Jabłoński 2011: 480). Pielgrzymka wiąże się z trudem pokonywania odległości od miejsca zamieszkania do miejsca kultu religijnego. Trud ten jest ofiarowany Bogu w intencji oddania $\mathrm{Mu}$ czci, przebłagania za grzechy, podziękowania za otrzymane dary, bądź uproszenia łask (Jabłoński 2011: 480).

Tradycja pielgrzymowania jest obecna nie tylko w chrześcijaństwie, lecz także w religiach pozachrześcijańskich. W hinduizmie pielgrzymki odbywają się do znanych miejsc geograficznych, na przykład do siedmiu rzek uznawanych za święte: Gangesu, Indusu, Jamuny, Narbady, Godawari, Kaweri oraz mitycznej Saraswati. W buddyzmie celem pielgrzymek są miejsca związane z życiem Buddy (na przykład Lumbini koło Kapilawastu w Nepalu - miejsce narodzin — czy Sarnath — miejsce wygłoszenia pierwszego kazania). Islam nakłada na wyznawców obowiązek nawiedzenia Mekki, czyli, jak wierzą wyznawcy islamu, miejsca urodzenia Mahometa. W tradycji żydowskiej pierwszymi miejscami pielgrzymkowymi były Betel, gdzie przez pewien czas przechowywano Arkę Przymierza, oraz Beer Szeba i Hebron, 
czyli najstarsze sanktuaria związane z opowiadaniami o Abrahamie i pozostałych patriarchach (Jabłoński 2011: 480-482). „Najważniejszym ośrodkiem pielgrzymkowym w czasach ST [Starego Testamentu - R.W.] była Jerozolima, dokąd przeniesiono Arkę Przymierza [...], czczona jako Miasto Święte, a w niej świątynia jerozolimska [...]" (Jabłoński 2011: 483).

W chrześcijaństwie pielgrzymki miały wymiar pobożności wspólnotowej lub indywidualnej formy zadośćuczynienia Bogu za grzechy. Celem pierwszych pielgrzymek chrześcijańskich, podobnie jak żydowskich, była Jerozolima i świątynia jerozolimska. Dodatkowo czczono miejsca związane z Męką Pańską i zmartwychwstaniem Chrystusa. Po zajęciu Palestyny przez Arabów ruch pielgrzymkowy osłabł. Jednak pielgrzymi po powrocie w strony rodzinne budowali pamiątkowe kopie budowli, na przykład Grobu Pańskiego i wzniesionej nad nim bazyliki, i one również stawały się celem peregrynacji. Głównym ośrodkiem pielgrzymkowym średniowiecznej Europy było Santiago de Compostela. Jednak od czasów reformacji nastąpiło załamanie ruchu pielgrzymkowego, który odrodził się po II wojnie światowej, apogeum rozwoju osiągnął zaś na przełomie drugiego i trzeciego tysiąclecia. Współcześnie najczęściej nawiedzane są miejsca czci Najświętszej Maryi Panny - związane z Jej objawieniami bądź przechowywaniem cudownych wizerunków (Jabłoński 2011: 485-487).

Tradycja pielgrzymkowa w Polsce sięga czasów plemion pogańskich i związana jest z kultem wytworów przyrody (na przykład drzew, gór, wody) uznanych za święte. Przykładem mogą być Ślęża, Łysa Góra, Radogoszcz. Za pierwszą pielgrzymkę chrześcijańską uważa się przybycie Ottona III do grobu św. Wojciecha w Gnieźnie. Ruch pielgrzymkowy związany był z kultem relikwii (na przykład Święty Krzyż, gdzie przechowywano relikwie Krzyża) i świętych (na przykład Trzebnica związana z kultem świętej Jadwigi Śląskiej). Od przełomu XIX i XX wieku najważniejszym ośrodkiem pielgrzymkowym stała się Jasna Góra (Jabłoński 2011: 491-493). Polskie pielgrzymki miały rys specyficzny:

[...] na natężenie ruchu pątniczego 1772-1918 znaczny wpływ wywarła utrata niepodległości po III rozbiorze Polski i uwarunkowania społ.-gosp.; państwa zaborcze, a zwł. Prusy i Rosja, konsekwentnie zmierzały do asymilacji społeczeństwa pol., w czym za główną przeszkodę uważały Kościół kat. wykazujący znaczną dynamikę pątniczą i masowość praktyk religijnych; pielgrzymki obok treści religijnych, zawierały również elementy natury patriotycznej i często stanowiły okazję do demonstracji skierowanej przeciwko zaborcom; organizowane były także specjalne pielgrzymki do ośrodków związanych z dziejami Rzeczypospolitej, zwłaszcza do Gniezna, Krakowa, Warszawy, Wilna, co określano jako pątnictwo narodowe. (Jabłoński 2011: 493)

Znaczenie pielgrzymki nie ogranicza się jedynie do formy uczczenia istoty boskiej. Na polskim przykładzie widać, że pielgrzymki mogą charakteryzować się dodatkowymi, swoistymi atrybutami, które są związane z bieżącą sytuacją społeczną czy polityczną danego miejsca. 


\section{Pielgrzymka — wydarzenie medialne}

Daniel Dayan i Elihu Katz zdefiniowali wydarzenie medialne jako swoistą kategorię gatunkową: „[...] uroczystość, która stanowi wyłom w codzienności (syntaktyka), której uświęcone treści traktowane są z namaszczeniem (semantyka), a oddana widownia czynnie w niej uczestniczy (pragmatyka)" (Dayan, Katz 2008: 54). Tak opisana uroczystość dzieje się w mediach, a dokładniej — zdaniem wymienionych medioznawców - w telewizji, bo właśnie obecność w telewizji jakby konstytuuje medialność wydarzenia.

Podstawową cechą wydarzenia medialnego jest jego niecodzienność, która przyciąga i nakazuje odejście od rutynowych, powszednich czynności. Rozgrywa się ono na żywo poza mediami, które je relacjonują. Zwykle jest planowane z dużym wyprzedzeniem, dlatego też wydarzeniami medialnymi nie będą zdarzenia nagłe, na przykład zamach na Papieża czy awaria w elektrowni jądrowej, które jako niespodziewane zapełniają serwisy informacyjne. Dayan i Katz zwracają szczególną uwagę na sposób prezentowania wydarzeń medialnych, a zwłaszcza na rewerencję i ceremonialność z tym związaną. Wyraża się to między innymi w szczególnym sposobie wypowiadania się dziennikarzy, którzy przemawiają w sposób uroczysty i podniosły:

Uroczyste transmisje elektryzują ogromną widownię: cały naród, kilka krajów, świat. Zafascynowana publiczność wstrzymuje oddech. Oglądanie ich stanowi normę, bo ludzie przekazują sobie, że nie wolno przepuścić okazji, trzeba wszystko rzucić i zasiąść przed telewizorem [...] widzowie gromadzą się przed telewizorem, przedkładając zbiorowe świętowanie nad oglądanie w pojedynkę. [...] Uroczysta transmisja integruje społeczeństwo: we wspólnym rymie serc odradza się więź społeczna i uprawomocnia władza. (Deyan, Katz 2008: 48)

Pielgrzymki papieskie zostały przez Dayana i Katza zaliczone do kategorii nazwanej przez nich konkwistą. Obejmuje ona wydarzenia, których bohaterowie to „[...] herosi przekraczający rzekome prawa natury i społeczeństwa” (Deyan, Katz 2008: 70). Bohater konkwisty dokonuje wielkich czynów, zmienia bieg historii. Powoduje, że świat po jego słowach i czynach nie jest już taki sam. Uwodzi ludzi swoją charyzmą, która wynika z faktu przekraczania granic (Deyan, Katz 2008: 84).

Zgodnie z powyższą interpretacją wydarzenie medialne, jakim była pielgrzymka papieska do Polski, miało swojego bohatera - Papieża przekraczającego nie tylko granice państw, lecz także systemów politycznych. Przybył sam na terytorium, gdzie władza była w stosunku do niego wroga. Wydarzenie to zaplanowano dużo wcześniej: negocjacje między Episkopatem a władzą w sprawie drugiej pielgrzymki toczyły się wiele miesięcy przed pielgrzymką, a samo zaproszenie do złożenia wizyty w Polsce zostało skierowane 19 marca 1983 roku, czyli na trzy miesiące przed samą wizytą (Polak 2019: 142). Relacja z niej odbywała się na żywo w telewizji. Wydarzenie poruszało wielkie rzesze odbiorców: liczba uczestników pierwszej pielgrzymki papieskiej była oceniana nawet na $10 \mathrm{mln}$ wiernych, w przypadku drugiej - na 7 mln, zaś trzeciej — na ponad 5 mln (Przastek, Mrowiński 2019: 400). Pielgrzymki 
papieskie wpływały na bieg historii, czego najbardziej wyrazistym przykładem jest pielgrzymka pierwsza, z roku 1979. Przełomowe słowa: „Wołam, ja, syn polskiej ziemi, a zarazem ja, Jan Paweł II, papież, wołam z całej głębi tego Tysiąclecia, wołam w przeddzień Święta Zesłania, wołam wraz z wami wszystkimi: Niech zstąpi Duch Twój! Niech zstąpi Duch Twój! I odnowi oblicze ziemi! Tej ziemi! Amen" (Pielgrzymka Jana Pawła II do Polski 1979: 24) wypowiedziane w Warszawie 2 czerwca 1979 roku w pierwszym dniu pielgrzymki „[...] umocniły zarówno ludzi wierzących, jak i tych, dla których Kościół stanowił ostoję w walce z komunizmem, w przekonaniu, że tylko wspólne, solidarne działania mogą poszerzyć granice wolności” (Polak, Kufel, Ruchlewski 2019: 10). Dwie kolejne pielgrzymki również miały swoje ważne znaczenie: druga „[...] podtrzymała ducha w społeczeństwie, dała nadzieję na lepsze jutro” (Polak, Kufel, Ruchlewski 2019: 10); trzecia zaś „[...] stała się okazją do zamanifestowania obecności Solidarności i dała fundament transformacji ustrojowej” (Polak, Kufel, Ruchlewski 2019: 10).

\section{Papieskie pielgrzymki do Polski}

W czasie swojego pontyfikatu Jan Paweł II osiem razy odwiedzał Polskę: pierwszy raz w roku 1979, a po raz ostatni - w roku 2002 (www2). Wizyty te nazywane są pielgrzymkami, co wynika z tego, że Papież przede wszystkim odwiedzał ważne miejsca kultu religijnego, na przykład Jasną Górę, Kalwarię Zebrzydowską, sanktuarium $\mathrm{w}$ Łagiewnikach. Celem były także Wadowice - miasto rodzinne, a także inne miejscowości, w których spotykał się z wiernymi, na przykład Warszawa, Gniezno, Wrocław, Kraków, Katowice, Legnica, Tarnów czy Łódź.

Warto wspomnieć, że spotkania $\mathrm{z}$ wiernymi odbywały się nie tylko w miejscach uświęconych religijnie, ale często tam, gdzie mogła się zgromadzić wielotysięczna liczba uczestników mszy świętych, podczas których często odbywały się koronacje cudownych obrazów czy beatyfikacje ${ }^{1}$. Jan Paweł II spotykał się z wiernymi nie tylko przy okazji odprawiania mszy. Do historii przeszły spotkania w Krakowie pod tak zwanym oknem papieskim przy ulicy Franciszkańskiej, z którego Papież prowadził swoisty dialog ze zgromadzonymi tam wiernymi. Oprócz spotkań ze znaczną liczbą wiernych były też spotkania kameralne, jak choćby z Lechem Wałęsą w schronisku w Dolinie Chochołowskiej.

Wizyty Jana Pawła II miały wymiar nie tylko religijny, lecz także polityczny, bowiem papież jest również głową państwa watykańskiego. $\mathrm{Z}$ tego też powodu jest w nich widoczny aspekt dyplomatyczny i dlatego Jan Paweł II był podejmowany przez polskie władze. Podczas pielgrzymek w latach osiemdziesiątych spotykał się z przewodniczącym Rady Państwa Henrykiem Jabłońskim oraz z generałem Woj-

${ }^{1}$ Przykładowo, podczas drugiej pielgrzymki na mszy świętej we Wrocławiu Jan Paweł II koronował obraz Matki Boskiej Śnieżnej, z kolei w trakcie trzeciej pielgrzymki dokonał beatyfikacji Karoliny Kózkówny (10 czerwca 1987 w Tarnowie). 
ciechem Jaruzelskim, który w tamtym czasie pełnił funkcje państwowe: premiera - podczas drugiej pielgrzymki - oraz przewodniczącego Rady Państwa w trakcie pielgrzymki trzeciej.

Oficjalne media, kontrolowane przez ówczesne władze, miały z wizytami Papieża pewien problem. Pojawił się on już przy okazji pierwszej pielgrzymki. Jak pisał Michał Głowiński:

I w nowomowie, tak uschematyzowanej i dobrze ułożonej, zdarzają się przygody. Skazana jest nie tylko na codzienną rutynę, także na to, by mówić o rzeczach niezwykłych, które nie śniły się prorokom, choć w pewnej chwili stały się - rzeczywistością. Do wydarzeń takich należała bez wątpienia papieska podróż po Polsce. Oficjalna prasa nie mogła o niej milczeć, choć pisanie na ten temat narażało na różnego rodzaju niedogodności. (Głowiński 1991: 68)

Dysponenci mediów oficjalnych narzucali opis pielgrzymki według

z góry ustalonych dyrektyw, zawartych w instrukcjach, które miały moc obowiązującą i regulowały nawet najmniejsze drobiazgi. [...] opisy papieskiej podróży, będąc [...] wzorcowym przykładem manipulowania informacjami i mową, obywają się bez jawnych kłamstw. Rzecz polega nie na pisaniu o tym, czego nie było, ale na przekazywaniu wiadomości cząstkowych, dobieraniu ich według ustalonej skali wartości, często wchodząc w konflikt nie tylko z powszechnym odczuciem, ale także — ze zdrowym rozsądkiem. (Głowiński 1991: 68)

Druga i trzecia pielgrzymka Jana Pawła II do Polski odbywały się w okolicznościach szczególnych. 13 grudnia 1981 roku Wojskowa Rada Ocalenia Narodowego wprowadziła w Polsce stan wojenny. Wiązały się z tym represje w stosunku do działaczy organizacji niezależnych od władzy, na przykład Niezależnego Samorządnego Związku Zawodowego „Solidarność, Niezależnego Zrzeszenia Studentów, Niezależnego Związku Zawodowego „Solidarność” Rolników Indywidualnych. Reakcją na wprowadzenie stanu wojennego było powstanie tajnych struktur organizacji zakazanych przez władze. Ich główną bronią $\mathrm{w}$ walce o swoje prawa stały się nielegalne wydawnictwa, czyli drugi obieg wydawniczy, który funkcjonował w opozycji do oficjalnych, kontrolowanych przez władze środków przekazu informacji.

Druga pielgrzymka Jana Pawła II do Polski (16-23 czerwca 1983 roku) odbywała się w warunkach zawieszonego stanu wojennego (31 grudnia 1982). Papież odwiedził Warszawę, Niepokalanów, Częstochowę, Poznań, Katowice, Wrocław, Górę św. Anny i Kraków. Trzecia pielgrzymka odbyła się w dniach 8-14 czerwca 1987. Podczas tej pielgrzymki Papież był w Warszawie, Lublinie, Tarnowie, Krakowie, Szczecinie, Gdyni, Gdańsku, Częstochowie i Łodzi.

Wizyty głowy państwa watykańskiego, a w dodatku Polaka wyniesionego na tak zaszczytne stanowisko były zawsze ważnym wydarzeniem i odbiły się echem również w niezależnym od władz drugim obiegu wydawniczym.

\section{„Tygodnik Mazowsze"}

Jednym z najważniejszych podziemnych periodyków lat osiemdziesiątych był „Tygodnik Mazowsze", który ukazywał się w Warszawie od 11 lutego 1982 roku do 12 kwiet- 
nia 1989 roku. Redakcja, wydając pierwszy numer czasopisma, nadała mu numer drugi, co nawiązywało do planów Zarządu Regionu Mazowsze NSZZ "Solidarność" wydawania oficjalnego, regionalnego tygodnika, niezrealizowanych z powodu wprowadzenia stanu wojennego. Bardzo zaawansowaną już organizacją tego pisma zajmował się Jerzy Zieliński, który w proteście przeciwko wprowadzeniu stanu wojennego popełnił samobójstwo. Właśnie nietypowa numeracja była symbolicznym znakiem pamięci o zmarłym redaktorze (www3), wspomnienie o nim zostało zaś umieszczone jako pierwszy artykuł w numerze ${ }^{2}$.

Redakcja „Tygodnika Mazowsze” tworzyła się wokół Heleny Łuczywo i Joanny Szczęsnej, które pierwotnie, w pierwszych dniach stanu wojennego, były zaangażowane w wydawanie „Informacji Solidarności”:

Prawie wszyscy członkowie redakcji „Informacji Solidarności” i „Tygodnika Solidarność” wywodzili się ze środowiska współtworzącego KOR, skupionego w poprzednich latach głównie wokół Jacka Kuronia i Adama Michnika. To te dwie postaci były głównymi autorytetami politycznymi dla tego środowiska. (Olaszek 2018: 99)

O wyjątkowym miejscu „Tygodnika Mazowsze” wśród czasopism podziemnych decydowało kilka czynników. Jednym z nich była bliska relacja redakcji z ukrywającymi się działaczami władz regionalnych „Solidarności”. Z redaktorkami już $\mathrm{w}$ pierwszych tygodniach stanu wojennego nawiązali kontakt liderzy podziemia z innych regionów (Olaszek 2018: 101). „Tygodnik Mazowsze” miał także wysoki, jak na warunki podziemne, nakład. Wynosił on około 50 tys. egzemplarzy: „tak wysokie liczby nakładu stanowiły dorobek nie tylko struktur bezpośrednio związanych z pismem, lecz także wielu innych, które uczestniczyły w jego druku i kolportowaniu” (Olaszek 2018: 263). Na popularność „Tygodnika Mazowsze” wpływało to, że znajdował on "bardzo wielu czytelników w innych ośrodkach — zarówno tych mniejszych, jak i największych. Ruch w drugą stronę odbywał się na znacznie mniejszą skalę" (Olaszek 2018, 263). Pozycję czasopisma wzmacniały nie tylko wartości merytoryczne, lecz także pomoc finansowa oraz to,

że działacze „Solidarności” z innych województw uznawali ich [pism wydawanych w Warszawie R.W.] prymat, nie próbowali go podważać, chętnie je drukowali i kolportowali w swoich miastach. [...] podziemne pisma wydawane w Warszawie, zwłaszcza „Tygodnik Mazowsze”, „Tygodnik Wojenny” czy „Przegląd Wiadomości Agencyjnych”, były traktowane jako dobro wspólne jego uczestników niezależnie od tego, gdzie działali. (Olaszek, 2018: 263)

\section{Zakres analizowanego materiału}

Analizowany materiał obejmuje artykuły, które dotyczyły drugiej (16-23 czerwca 1983) i trzeciej (8-14 czerwca 1987) pielgrzymki papieskiej i ukazały się w „Tygodniku Mazowsze" w czasie trwania pielgrzymek, w okresie je poprzedzającym lub zaraz po nich. Teksty odnoszące się do drugiej pielgrzymki zostały opublikowane w nu-

\footnotetext{
${ }^{2}$ Redakcja, Słowo o Jerzym Zieleńskim, „Tygodnik Mazowsze” nr 2, 11.02.1982, s. 1.
} 
merach: 43 (3 marca 1983), 45 (24 marca 1983), 46 (7 kwietnia 1983), 47 (14 kwietnia 1983), 51 (12 maja 1983), 53 (26 maja 1983), 54 (2 czerwca 1983), 55 (23 czerwca 1983), 56 (30 czerwca 1983), 57 (14 lipca 1983) i 58 (28 lipca 1983). Temat trzeciej pielgrzymki jest obecny w numerach: 209/210 (6 maja 1987) 213 (27 maja 1987), 214 (2 czerwca 1987), 215 (17 czerwca 1987), 216 (1 lipca 1987) oraz w numerze specjalnym „Tygodnika Mazowsze” pod winietą: „Fotoaneks Fotograficznej Agencji Solidarność" nr 4 (8-14 czerwca 1987).

O znaczeniu pielgrzymek papieskich w „Tygodniku Mazowsze” świadczyć może ilość poświęconego im miejsca. Temat pielgrzymek papieskich pojawia się dużo wcześniej przed pielgrzymkami, w przypadku drugiej pielgrzymki - na trzy miesiące przed nią, a w przypadku trzeciej - na miesiąc. Redakcja „Tygodnika Mazowsze" wydawała także numery monograficzne poświęcone tylko pielgrzymkom. W roku 1983 jest to numer 55., a w roku 1987 - numer 215. Przy okazji trzeciej pielgrzymki ukazuje się także numer wyjątkowy, bo złożony z samych fotografii. O szczególności tego numeru specjalnego świadczy to, że „Tygodnik Mazowsze” nie umieszczał fotografii na swoich łamach. Temat pielgrzymek nie kończy się też z zakończeniem wizyt Ojca Świętego, lecz jest kontynuowany w kolejnych numerach. W 1983 roku pielgrzymka jest tematem jeszcze miesiąc po jej zakończeniu, z kolei cztery lata później ostatnie teksty dotyczące trzeciej pielgrzymki pojawiają się dwa tygodnie po niej. Chociaż w tym przypadku mogło to wynikać z rytmu wydawania czasopisma - był to kolejny numer, który ukazał się po pielgrzymce.

Częstotliwość ukazywania się materiałów dotyczących pielgrzymek pozwala uchwycić różnice w traktowaniu obu tych wizyt: redaktorzy „Tygodnika Mazowsze” są zdecydowanie mniej zainteresowani trzecią pielgrzymką, niż byli zainteresowani drugą. Tekstów dotyczących trzeciej pielgrzymki jest znacząco mniej, bo ukazują się w sześciu numerach czasopisma, podczas gdy w przypadku drugiej pielgrzymki było to jedenaście numerów.

Analiza tekstów pozwala na wyodrębnienie kategorii tematycznych, które będą swoistymi wymiarami opisu pielgrzymek: wymiar religijny (fragmenty homilii, relacje z mszy), wymiar społeczno-polityczny (wydarzenia nawiązujące do sytuacji społeczno-politycznej w Polsce), wymiar artystyczny (utwory artystyczne) i obraz władz (opis działania instytucji związanych z władzą).

\section{Wymiar religijny}

Pielgrzymka ma przede wszystkim znaczenie religijne. Wyrazem tego w „Tygodniku Mazowsze" są cytowane fragmenty papieskich homilii czy relacje z pobytu Papieża w miejscach kultu religijnego. Wymiar ten pojawia się w momencie przyjazdu Papieża. W numerze 55. znaczną większość miejsca poświęcono fragmentom homilii papieskich. Na pierwszej stronie zaczyna się długi, kontynuowany na kolejnych stronach aż do końca numeru, tekst Jan Paweł II swojemu narodowi, który 
zawiera fragmenty papieskich homilii z kolejnych miejsc spotkań z wiernymi, na przykład:

Warszawa, katedra, $16 \mathrm{VI}$

Wszyscy stoimy pod krzyżem. Cała ludzkość wciąż stoi pod krzyżem. Nasz naród od tysiąca lat stoi pod krzyżem. Pozwólmy się ogarnąć tajemnicy Odkupienia: tajemnicy Syna Bożego! W niej to odsłania się także do końca jakże nieraz trudna do rozwikłania tajemnica człowieka. I okazuje się, poprzez wszystkie cierpienia i upokorzenia jego - człowieka — najwyższe powołanie.

Wraz z wszystkimi Rodakami - zwłaszcza tymi, którzy najboleśniej czują cierpki smak zawodu, upokorzenia, cierpienia, pozbawienia wolności, krzywdy, podeptania godności człowieka, staję pod krzyżem Chrystusa, aby z ziemi polskiej odprawiać nadzwyczajny jubileusz Roku Odkupienia ${ }^{3}$.

Redakcja nie publikowała w całości wystąpień papieskich, co mogło wynikać choćby ze względów prozaicznych, czyli braku odpowiedniej ilości miejsca w numerze. Jakie jednak mogły być kryteria wyboru tych fragmentów? W powyższym cytacie są odwołania jednoznacznie religijne (na przykład „tajemnica Odkupienia: tajemnica Syna Bożego”). Jednak oprócz kontekstu religijnego jest też nawiązanie do sytuacji społeczno-politycznej, bo za takie można uznać słowa: „Wraz z wszystkimi Rodakami - zwłaszcza tymi, którzy najboleśniej czują cierpki smak zawodu, upokorzenia, cierpienia, pozbawienia wolności, krzywdy, podeptania godności człowieka"4, wskazujące na kontekst polityczny i okoliczności wprowadzenia stanu wojennego („pozbawienie wolności”, „podeptanie godności człowieka”). Podobnie jest w przypadku innego fragmentu:

Błogosławieni, którzy łakną i pragną sprawiedliwości. Jest tutaj we Wrocławiu — tutaj: na Dolnym Śląsku — jest w całej Polsce wielu ludzi, ogromnie wielu ludzi, którzy łakną i pragną sprawiedliwości. Myślę w tej chwili o ludziach ciężkiej, codziennej pracy [...] Wszystkim wam, którzy wypełniając przykazanie Stwórcy, czynicie sobie ziemię poddaną, przynoszę solidarność moją i Kościoła.

To łaknienie i pragnienie sprawiedliwości ujawniło się w sposób szczególny w ciągu ostatnich lat. Pragnę bardzo, jako pasterz Kościoła, a zarazem jako syn mojego narodu, potwierdzić to łaknienie i pragnienie, które płynie ze zdrowych pokładów ducha polskiego: z poczucia godności ludzkiej pracy, z miłości Ojczyzny oraz z solidarności, czyli z poczucia wspólnego dobra 5 .

W powyższym fragmencie Papież przytacza Kazanie na Górze, które umieszcza w kontekście sytuacji politycznej ówczesnej Polski, gdzie są ludzie pragnący sprawiedliwości „w sposób szczególny w ciągu ostatnich lat”. Jest to czytelna sugestia o braku sprawiedliwości. Redakcja, publikując fragmenty, dokonuje selekcji i wskazuje, które treści są z jej punktu widzenia ważne, a te wiążą się z kontekstem społeczno-politycznym tamtego czasu.

Podobnie jest w przypadku trzeciej pielgrzymki. W numerze 215. „Tygodnika” zamieszczone zostały relacje z mszy i spotkań oraz fragmenty papieskich homilii, na przykład z mszy na gdańskiej Zaspie:

\footnotetext{
${ }^{3}$ Jan Paweł II swojemu narodowi, „Tygodnik Mazowsze” nr 55, 23.06.1983, s. 1.

${ }^{4}$ Ibidem.

${ }^{5}$ Ibidem, s. 3.
} 
„Jeden drugiego brzemiona noście” — to zwięzłe zdanie Apostoła jest inspiracją do międzyludzkiej i społecznej solidarności (oklaski). Solidarność to znaczy: jeden i drugi, a skoro brzemię, to brzemię niesione razem we wspólnocie. [...] Nie może być walka silniejsza od solidarności (okrzyki, okrzyki „Solidarność”). Właśnie chcę o tym mówić (oklaski), więc pozwólcie się wypowiedzieć Papieżowi, skoro chce mówić o Was, a także - w pewnym sensie - za Was. [...] Nie może być program walki ponad programem solidarności. Inaczej rosną zbyt ciężkie brzemiona ${ }^{6}$.

W tym przypadku, podobnie jak cztery lata wcześniej, redakcja wybiera fragment homilii, w którym Papież nawiązuje do aktualnej sytuacji. Papież wspomina o solidarności (pisanej przez małe „s”). Redakcja w zapisie reakcji wiernych zgromadzonych na Zaspie używa też słowa „solidarność”, ale pisze je wielką literą „S”, czyli interpretuje jak nazwę własną zakazanego związku zawodowego.

Z homilii wygłoszonej w Szczecinie redaktorzy „Tygodnika Mazowsze” wybrali fragment:

W latach osiemdziesiątych Szczecin był miejscem doniosłych wydarzeń - i doniosłych umów między władzami państwowymi a przedstawicielami świata pracy. Jaki był sens tych umów? Czyż nie chodziło o wszystko, co odpowiada godności ludzkiej pracy — i godności człowieka pracy? Mężczyzny i kobiety?

Praca ludzka: czyż nie jest ona równocześnie stałym punktem odniesienia całego społeczeństwa, a w tym społeczeństwie — każdej rodziny? [...]

Natura i posłannictwo rodziny stanowi najbardziej odpowiedzialną służbę społeczną, a zatem rodziny mają prawo do takich warunków bytowych, które by gwarantowały odpowiadający ich godności poziom życia i właściwy rozwój. Chodzi tutaj o słuszne wynagrodzenia za pracę. Chodzi o dach nad głową, o mieszkanie, poczynając od młodych małżeństw i rodzin dopiero się zawiązujących $[\ldots]^{7}$.

Papież przywołuje umowy podpisane w Szczecinie 30 sierpnia 1980 roku. Jest to pretekst, by nawiązać do sytuacji społecznej rodzin i konieczności zagwarantowania im godnego życia.

Kontekst religijny pojawia się nie tylko we fragmentach homilii papieskich, lecz także w komentarzach. Przykładem może być artykuł Nowa katecheza, w którym czytamy: "Pielgrzymka przyniosła potężne przesłanie przede wszystkim Kościoło-

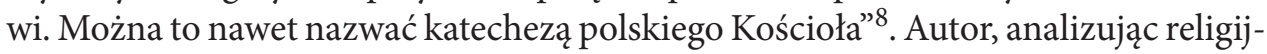
ne konteksty trzeciej pielgrzymki, zauważył, że Papież wyprowadził „Solidarność” $\mathrm{z}$ wąskiego rozumienia, z kontekstu politycznego na wyższy, uniwersalny poziom:

Homilia wygłoszona w Gdyni na spotkaniu z ludźmi morza zawiera fundamentalną analizę tego wielkiego doświadczenia, jakim było doświadczenie "Solidarności« — wskazuje na jego uniwersalny wymiar. [...] Bowiem dokonanie »Solidarności« niesie ważkie posłanie uniwersalne, odnoszące się też do Kościoła. W istotny sposób pozostaje w związku z doktryną społeczną Kościoła, wypływa z niej, ale także ją karmi”"9.

\footnotetext{
${ }^{6}$ Ojciec Święty w Trójmieście, „Tygodnik Mazowsze” nr 215, 17.06.1987, s. 2.

7 Szczecin 11 czerwca. Jan Paweł II podczas mszy św. dla rodzin, „Tygodnik Mazowsze”, nr 216, 17.06.1987, s. 3.

8 W.K., Nowa katecheza, „Tygodnik Mazowsze” nr 215, 17.06.1987, s. 1.

9 Ibidem, s. 2.
} 


\section{Wymiar społeczno-polityczny}

Przed każdą wizytą papieską ukazywały się w „Tygodniku Mazowsze” teksty, które wyrażały oczekiwania związane z pielgrzymką. W 1983 roku był to artykuł W oczekiwaniu na Ojca Świętego, z kolei cztery lata później była to dyskusja redakcyjna Gdzie religia łączy się z polityką. Wymowa tych dwóch tekstów jest jednak różna. Widoczna jest wyraźna zmiana z entuzjazmu, jaki charakteryzował oczekiwanie na Papieża w roku 1983, na sceptycyzm związany z pielgrzymką w roku 1987.

Wiarę w siłę oddziaływania Papieża widać przed drugą wizytą:

Spotkania z Janem Pawłem II odsłaniają w ludziach to, co w nich dobre i godne, ukazują ów wieczny pierwiastek boski, budzą nadzieję. A dzisiaj potrzeba nam przede wszystkim wiary w samych siebie, w moc zbiorowego tworzenia, w siłę prawa, w to, że będziemy żyli bez stałego lęku i zagrożenia. Wiara ta realizuje się w spokoju i godności wiernych zgromadzonych na trasie papieskiej pielgrzymki, w tej rzadkiej i uroczystej serdeczności i cieple, jakie sobie wtedy dajemy, w poczuciu bliskości z Papieżem. Wtedy widzimy, że możemy żyć inaczej, że codzienne zmęczenie nie musi wisieć nad nami jak fatum, że należy się nam i że sami możemy, a nawet musimy tworzyć ład, w którym chociażby nie łamie się co chwilę podstawowych przykazań ${ }^{10}$.

Nie ma takiego entuzjazmu w wypowiedziach anonimowych uczestników dyskusji z roku 1987. Są oni krytycznie nastawieni do wizyty Ojca Świętego. Padają głosy o zniechęceniu: „Podróżowałem ostatnio trochę po Polsce, rozmawiałem z ludźmi i zauważyłem, że niewiele się spodziewają po tej pielgrzymce. Zbanalizował się sam fakt przyjazdu Papieża - przecież będzie to już po raz trzeci”11; alienacji Kościoła: „Być może poziom społecznych oczekiwań jest tak niski, gdyż w powszechnym odczuciu do pielgrzymki przygotowuje się Kościół wspólnie z władzą, a ludzie czują się odsunięci”12; osłabieniu nastrojów społecznych: „[...] że tym razem trudno znaleźć chętnych do kościelnych służb porządkowych. [...] Nie zdziwiłbym się, gdyby społeczne zainteresowanie tą pielgrzymką było mniejsze niż poprzednimi"13. Ten krytyczny ton wypowiedzi jest czymś zdecydowanie odmiennym od tonu tekstów sprzed czterech lat, kiedy to skupiano się na entuzjazmie wiernych i na jednoznacznie pozytywnych oczekiwaniach w stosunku do przyjazdu Papieża. To ważna zmiana w postrzeganiu wizyty papieskiej przez redakcję „Tygodnika Mazowsze”.

Wymiar społeczno-polityczny pielgrzymki papieskiej jest realizowany w opisach spotkań z wiernymi poza mszami, opisach spotkań z władzami państwowymi, reakcjach działaczy podziemnych na pielgrzymki oraz opublikowanych hasłach z transparentów na mszach papieskich lub na trasie przejazdu Papieża.

${ }^{10}$ WNS, W oczekiwaniu na Ojca świętego, „Tygodnik Mazowsze”, nr 45, 24.03.1983, s. 2.

${ }^{11}$ Gdzie religia łączy się z polityką. Dyskusja przed pielgrzymka Jana Pawła II, „Tygodnik Mazowsze" nr 213, 27.05.1987, s. 1.

12 Ibidem.

${ }^{13}$ Ibidem. 


\section{Reakcje działaczy i organizacji podziemnych}

Jeszcze na dwa miesiące przed przyjazdem Papieża TKK [Tymczasowa Komisja Koordynacyjna - R.W.] NSZZ „Solidarność” wydała opublikowane w numerze 46 „Tygodnika Mazowsze” Oświadczenie, w którym pisała: „Miliony Polaków zrzeszonych w NSZZ „Solidarność” z radością oczekują przyjazdu Ojca Świętego do Ojczyzny. Dla nas jest to wizyta pokoju i nadziei" ${ }^{14}$. Autorzy przypomnieli o losie obywateli: „rodziny opłakują zabitych i uwięzionych [...] podeptano podstawowe prawa człowieka [...]"15. Wraz z oświadczeniem TKK wydała również dokument zatytułowany Ojcze Święty, w którym zwracała się bezpośrednio do Papieża:

W imieniu członków NSZZ „Solidarność” przesyłamy wyrazy głębokiej czci i oddania. Udręczone społeczeństwo czeka na spotkanie z Tobą. Potrzebujemy go dziś bardziej niż kiedykolwiek. Liczymy, że to spotkanie umocni w nas nadzieję, wiarę i miłość: fundamenty ideowe naszego ruchu, z których wyrośliśmy i którym pragniemy pozostać wierni ${ }^{16}$.

Przed drugą pielgrzymką ukazał się też wywiad z ukrywającym się wówczas Zbigniewem Bujakiem. Redakcja już na początku pyta o nadchodzącą wizytę Papieża. Bujak odpowiada, że:

każdy, kto będzie na tę wizytę patrzył pod kątem bezpośrednich, namacalnych efektów, pewnie niczego się nie doczeka. Bo ona nic takiego nie może przynieść i nawet nie wolno tego od niej oczekiwać. [...] Czego oczekuję po tej wizycie? Że pozwoli ludziom nie ustać $\mathrm{w}$ drodze, nie ustawać $\mathrm{w}$ walce ${ }^{17}$.

Kilka dni przed trzecią pielgrzymką na pierwszej stronie ukazało się powitanie Jana Pawła II przez Tymczasową Radę NSZZ „Solidarność”, Tymczasową Komisję Koordynacyjną NSZZ „Solidarność” oraz przewodniczącego NSZZ „Solidarnośćc Lecha Wałęsę zatytułowane Ojcze Święty. Autorzy wyrazili oczekiwania, jakie wiążą z pielgrzymką: „Polska potrzebuje dziś chleba i wolności, a nade wszystko potrzebuje nadziei. Jesteśmy przekonani, że spotkanie z Tobą i Twoim słowem polską nadzieję odrodzi”" ${ }^{18}$. W tym samym numerze zostało opublikowane oświadczenie osób zaproszonych przez Lecha Wałęsę na spotkanie 31 maja 1987 roku. W grupie tej znaleźli się naukowcy, działacze społeczni, dziennikarze, ekonomiści, działacze związkowi, rolnicy i inni. Przypomnieli oni najważniejsze cele, o które walczyła wówczas opozycja demokratyczna: „Polacy [...] mają prawo do niepodległości [...] mają prawo do życia $w$ demokracji, wolności, prawdzie, poszanowaniu prawa. [...] mają prawo do samodzielnego kształtowania ładu gospodarczego"19.

14 TKK NSZZ „Solidarność”, Oświadczenie, „Tygodnik Mazowsze” nr 46, 7.04.1983, s. 1.

15 Ibidem.

16 TKK NSZZ „Solidarność”, Ojcze Święty, „Tygodnik Mazowsze” nr 46, 7.04.1983, s. 1.

${ }^{17}$ Nie ustawać w drodze. Rozmowa ze Zbigniewem Bujakiem, „Tygodnik Mazowsze” nr 53, 26.05. 1983, s. 1.

18 Tymczasowa Rada NSZZ „Solidarność”, Tymczasowa Komisja Koordynacyjna NSZZ „Solidarność” oraz Przewodniczący NSZZ „Solidarność” Lech Wałęsa, Ojcze Święty, „Tygodnik Mazowsze” nr 214, 3.06.1987, s. 1 .

${ }^{19}$ Grono osób zaproszonych..., „Tygodnik Mazowsze” nr 214, 3.06.1987, s. 1. 
W numerze 213. ukazała się krótka odezwa Tymczasowej Komisji Koordynacyjnej, która stwierdziła, że członkowie „Solidarności” mają moralne prawo zamanifestowania dążeń narodowych i społecznych, mają także prawo i obowiązek walki o legalną działalność Związku. TKK wezwała do udekorowania domów, ulic i miast flagami i emblematami narodowymi i związkowymi. Zachęcała też do udziału w spotkaniach z Papieżem ${ }^{20}$.

Dokumenty podziemnych organizacji wyrażają radość z wizyty Papieża i nadzieję, że spowoduje ona zmiany społeczne. Może się to wiązać z efektem, jaki nastąpił po pierwszej pielgrzymce z roku 1979, po której, jak się uważa, doszło do zmian społecznych w roku 1980.

Kolejne teksty władz organizacji niezależnych pojawiają się już po pielgrzymkach. Dominują w nich podziękowania za wizytę oraz jej podsumowania.

Już w pierwszym numerze po pielgrzymce w roku 1983 opublikowano podziękowanie $\mathrm{w}$ formie swego rodzaju adresu skierowanego do Jana Pawła II od Zbigniewa Bujaka, które przekazał w imieniu związkowców, regionalnych władz NSZZ „Solidarność" oraz własnym. Ma ono charakterystyczny, dziękczynny nagłówek: Bóg zapłać Ojcze Święty. Jeden z liderów podziemia pisał: „Darów Twoich w godzinie próby potrzebowaliśmy i potrzebujemy bardziej aniżeli kiedykolwiek indziej. Potrzebujemy ich, aby nie ustać w drodze, jaką każe nam podążać nasze sumienie i w jakiej podtrzymuje nas Twoje pielgrzymowanie" 21 .

Z kolei na pierwszej stronie numeru 57. „Tygodnik Mazowsze” publikuje oświadczenie Tymczasowej Komisji Koordynacyjnej NSZZ „Solidarność, w którym ukrywający się działacze zwracali uwagę na to, że „Pielgrzymka Papieża Polaka nadała właściwy sens słowom Prawda, Wolność, Sprawiedliwość"22. Wartości te autorzy oświadczenia odnoszą do sfery społeczno-politycznej i piszą: „Zjednoczyła ona [pielgrzymka - R.W.], niezależnie od wiary, wszystkich tych, którym bliskie są suwerenność narodu, podmiotowość społeczeństwa, godność człowieka i sens jego pracy, prawo swobodnego zrzeszania się"23.

Również w numerze 57. został opublikowany wywiad ze Zbigniewem Bujakiem Przesłanie dla „Solidarności”. Ukrywający się działacz już na samym początku zaznaczył, że „nauki Jana Pawła II przyjmujemy za podstawową inspirację naszego życia, naszej pracy i walki”"24. Nie brakuje też wątku społeczno-politycznego, związanego z nielegalnie działającym związkiem zawodowym: „Wszędzie tam, w okrzykach, pieśniach i transparentach obecna była »Solidarność «"25.

20 Tymczasowa Komisja Koordynacyjna, Do członków Związku, „Tygodnik Mazowsze” nr 213, 27.05.1987, s. 1 .

${ }^{21}$ Z. Bujak, Bóg zapłać Ojcze Święty, „Tygodnik Mazowsze”, nr 56, 30.06.1983, s. 1.

22 Oświadczenia Tymczasowej Komisji Koordynacyjnej, „Tygodnik Mazowsze” nr 57, 14.07.1983, s. 1.

${ }^{23}$ Ibidem.

${ }^{24}$ Przesłanie dla „Solidarności” wywiad ze Zbigniewem Bujakiem, „Tygodnik Mazowsze” nr 57, 14.07.1983, s. 1 .

${ }^{25}$ Ibidem. 
Także po zakończeniu trzeciej pielgrzymki ukazały się w „Tygodniku Mazowsze” oświadczenia władz podziemnych. W numerze 216. opublikowano kolejną rozmowę z Bujakiem, który podsumował wizytę Ojca Świętego. Działacz „Solidarności” wskazał na znaczenie papieskiej pielgrzymki dla wielu Polaków:

Znamy sytuację działaczy w małych miastach, w zakładach, którzy od jakiegoś czasu czuli się dość osamotnieni, obawiali się, że nagle pozostaną jako margines, nie wiadomo czy ważny, nie wiadomo czy poważny. I oto usłyszeli od najwyższego autorytetu, że "Solidarność” to wielka rzecz o światowej skali. Mają teraz jasną perspektywę, że i Papież wierzy w „Solidarność” i że trzeba trwać ${ }^{26}$.

Jednak rozmowa ma wydźwięk nie tylko optymistyczny, utwierdzając ludzi w gotowości do dalszej walki. Pojawia się w niej także wątek zniechęcenia społecznego: „Cały czas miałem wrażenie, że jest to tłum ludzi, nawet nie przygnębionych, tylko właśnie wyciszonych, którzy nie bardzo umieliby powiedzieć, po co przyszli, czego oczekiwali"27.

\section{Opis zachowania wiernych podczas mszy oraz spotkania z wiernymi poza mszami}

W opisach mszy papieskich redakcja zwracała uwagę na dużą liczbę wiernych, którzy w nich uczestniczyli:

Liczebność tłumów, które ściągnęły do leżącego na uboczu Niepokalanowa, przekroczyła wszelkie oczekiwania. Na wiele godzin przed rozpoczęciem mszy szosą poznańską wędrowały tłumy wiernych, pielgrzymki z parafii z transparentami i chorągwiami. Przybyły tam również delegacje internowanych ${ }^{28}$.

Co więcej, na opis zachowania uczestników jest wydzielona na każdej stronie numeru 55. skrajna szpalta. Znajdują się tam opublikowane reakcje wiernych podczas mszy papieskich:

Także w trakcie homilii ludzie niezwykle żywo reagowali na wszelkie odniesienia do Sierpnia i do aktualnej sytuacji politycznej. Przejmującym akcentem końcowym było odśpiewanie Boże, coś Polskę. Wszyscy podnieśli ręce na znak zwycięstwa. Tak było potem wszędzie ${ }^{29}$.

W tygodniku relacjonowano także spotkania okolicznościowe:

W piątek Ojciec Św. prosto z Belwederu pojechał do kościoła oo. Kapucynów na spotkanie z 250 przedstawicielami różnych środowisk, między innymi artystów, „Solidarności Wiejskiej”, Prymasowskiego Komitetu Pomocy przy kościele św. Marcina. Tu Papież rozmawiał z Barbarą Sadowską, matką Grzegorza Przemyka, i z Tadeuszem Mazowieckim ${ }^{30}$.

${ }^{26}$ To było nam ogromnie potrzebne. Z rozmowy ze Zbigniewem Bujakiem, „Tygodnik Mazowsze” nr 216, 1.07.1987, s. 1 .

27 Ibidem.

${ }^{28}$ Kronika wizyty, „Tygodnik Mazowsze”, nr 55, 23.06.1983, s. 1.

${ }^{29}$ Ibidem.

${ }^{30}$ Ibidem. 
Papież spotykał się z wiernymi nie tylko podczas mszy, lecz także przy innych okazjach. Takie spontaniczne spotkanie, podobne do najbardziej znanych spotkań pod oknem papieskim w Krakowie, odbyło się w Częstochowie w trakcie drugiej pielgrzymki:

Wieczorne spotkanie Ojca Świętego z młodzieżą było wydarzeniem niezwykłym nawet jak na tę pielgrzymkę. Oto dokładny zapis tego, co działo się przed Apelem Jasnogórskim:

Z głośnika: Polskie morze bardzo wzburzyło się na wiadomość, że Ojciec Święty nie będzie mógł pojawić się na Wybrzeżu. Burzliwe oklaski. Wszyscy śpiewają Petni mocy, wdzięczności i chwaty.

Długotrwałe okrzyki „Niech żyje Papież” i „Sto lat”.

Jan Paweł II: Chcę o coś zapytać (oklaski). Chciałbym zapytać, czy pewien człowiek z Rzymu, który przyjechał do Polski i dzisiaj jest na Jasnej Górze, ma prawo zabrać głos?

Wszyscy po wielokroć skandują: My Cię kochamy.

On: Czy nie mam prawa? - My Cię kochamy. Tak.

On: Uczynki przeczą.

Wśród okrzyków „My Cię kochamy” — Moi drodzy... Moi drodzy... Ja także Was bardzo kocham.

Wielka owacja, „Dziękujemy”.

On: Czy mam zejść niżej? - Tak.

On: Dlaczego nie mówicie wyraźnie? - My Cię kochamy.

On: Jakie jeszcze macie życzenia? - Zostań z nami.

On: Dopiero co przyjechałem. — Zostań z nami. Niech żyje Papież.

On: Mamy tu pewnych gości z zagranicy i pewnie sobie pomyślą, że młodzież polska jest bardzo gadatliwa. No to teraz pozwólcie mi się odezwać i rozważyć z Wami, tak jak przystoi na tę porę dnia, modlitwę zwaną Apelem Jasnogórskim ${ }^{31}$.

Spotkania z Papieżem miały kontekst religijny, ale zasadniczo były spotkaniami pozareligijnymi, o charakterze społeczno-politycznym. Ten wymiar był widoczny w zachowaniu tłumów, które przychodziły na msze, wracały z mszy lub były przy drodze przejazdu Papieża.

Numer 215. „Tygodnika Mazowsze” ukazał się 17 czerwca 1987 roku, już po pielgrzymce. Redakcja w reporterskim stylu opisała wszystkie miejsca, w których był Papież. Odnotowała słowa homilii, zachowanie wiernych, napisy na transparentach. Nie brakowało także głosów krytycznych w stosunku do wiernych i osób przygotowujących pielgrzymkę:

Warszawa - milion ludzi na Placu Defilad, ale w mieście niemal nie czuło się obecności Papieża.

[...] W stolicy tak 8 VI, jak 14 VI było raczej spokojnie. Podobnie w Lublinie, gdzie reakcje były bardzo powściągliwe. Atmosferę na łódzkim lotnisku określano wręcz jako apatyczną ${ }^{32}$.

Dużo miejsca poświęcono na sprawozdanie z wizyty Ojca Świętego w Trójmieście. W relacji ze mszy świętej na Zaspie pojawił się także motyw występowania Papieża w imieniu tych, którzy nie mogli się swobodnie publicznie wypowiadać. Przytaczane są słowa z papieskiej homilii: „Nie może być walka silniejsza od solidarności

\footnotetext{
${ }^{31}$ Ibidem, s. 1-2.

32 Na trasie pielgrzymki, „Tygodnik Mazowsze” nr 215, 17.06.1987, s. 1.
} 
(oklaski, okrzyki »Solidarność«). Właśnie chcę o tym mówić (oklaski), więc pozwólcie się wypowiedzieć Papieżowi, skoro chce mówić o Was, a także - w pewnym sensie - za Was"33.

W refleksjach zatytułowanych $\mathrm{Na}$ trasie pielgrzymki znajduje się konkluzja:

W całej pielgrzymce, może z wyjątkiem Zaspy, zabrakło poczucia, powszechnego przed 4 czy 8 laty — że tam, gdzie jest Papież i my z Papieżem, jesteśmy u siebie, a „oni”, w jakimkolwiek sensie tego słowa, są gdzieś obok ${ }^{34}$.

\section{Hasła na transparentach}

Po zakończeniu pielgrzymek redakcja „Tygodnika Mazowsze” publikowała hasła z transparentów, które pojawiały się podczas mszy lub na trasie przejazdu Papieża. Treści na transparentach najczęściej nawiązywały do sytuacji społeczno-politycznej.

Zestawienie haseł $\mathrm{z}$ drugiej pielgrzymki ukazało się w numerze 56. i było zatytułowane $\mathrm{Na}$ transparentach. Jednak nie zawierało ono tylko haseł (na przykład: „Wrocław: Witaj Ojcze Solidarności. Jesteśmy solidarni z Tobą. Solidarność z Bogiem. Robotnicy Elwro ufają Ci Ojcze Święty. Solidarność Jeleniogórska wita Ojca Świętego. Młodzież solidarna z Papieżem"35), lecz także okrzyki ze spotkań z Papieżem (na przykład „Niech żyje Papież. My z Papieżem, Papież z nami. Chodźcie z nami, dziś nie biją. Chodźcie z nami Polakami. Solidarność. Nie ma wolności bez Solidarności”36). Dużo jest w nich nazwy „Solidarność”. Redakcja na zakończenie napisała: „Żałujemy, że nie możemy przytoczyć wszystkich haseł i napisać ich najczęściej pojawiającym się liternictwem »S«"37.

Podobnie jak w roku 1983, redakcja „Tygodnika Mazowsze” opublikowała hasła i okrzyki wznoszone w trakcie trzeciej pielgrzymce:

W Warszawie: Trwaj z nami Ojcze Święty w solidarności + + + Czwarta pielgrzymka już do Wolnej Polski + + + Ojcze Święty kochamy Cię - dzieci z Wilanowa + + + Solidarność i rozwój tak, przemoc i nędza nie - Ruch „Odwaga i Prawda” Nowa Huta +++ Huta im. księdza Popiełuszki + + + Ojcze Święty nasze życie zniewala [- - - $]^{38}$ Solidarność Świdnik + + + Byliśmy w więzieniu i przyszedłeś do nas... ${ }^{39}$.

Transparenty są częstym motywem na zdjęciach w numerze specjalnym Tygodnika Mazowsze z 8-14 czerwca 1987. Są one pisane tak zwaną solidarycą, czyli czcionką o kroju podobnym do używanej w nazwie związku „Solidarność”. Oprócz transparentów, które wydają się głównym tematem numeru specjalnego, jest zdję-

\footnotetext{
33 Ojciec Święty w Trójmieście, „Tygodnik Mazowsze” nr 215, 17.06.1987, s. 2.

${ }^{34} \mathrm{Na}$ trasie pielgrzymki, op. cit., s. 4.

${ }^{35}$ Na transparentach, „Tygodnik Mazowsze” nr 56, 30.06.1983, s. 2.

${ }^{36}$ Ibidem.

37 Ibidem.

38 Znak graficzny używany w wydawnictwach oficjalnych w miejscu ingerencji cenzury.

39 Transparenty z różnych miast, „Tygodnik Mazowsze” nr 215, 17.06.1987, s. 3.
} 
cie Lecha Wałęsa na mszy papieskiej oraz zdjęcie Jana Pawła II przy grobie księdza Jerzego Popiełuszki ${ }^{40}$.

\section{Spotkania z przedstawicielami władz państwowych}

Jeszcze przed pielgrzymkami można znaleźć w tekstach „Tygodnika Mazowsze” rozważania dotyczące spotkań Papieża z przedstawicielami peerelowskich władz. Wiązało się to z wątpliwościami, czy powinien spotykać się z ludźmi, którzy wprowadzili stan wojenny:

Powiedzmy sobie otwarcie: byłoby nierozumnie oczekiwać, że Papież przyjeżdżający do Polski będzie robił afronty władzy. Należy więc przypuszczać (i nie dziwić się), że spotka się z jej przedstawicielami. Tak jak spotykał się gdzie indziej, co nigdy nie oznaczało, że akceptował niesprawiedliwość czy zbrodnię.

W 1979 roku Papież mówił w Belwederze do Gierka i jego towarzyszy o sumieniu, przed którym każdy musi się rozliczyć. Mówił też, że racją bytu państwa jest suwerenność społeczeństwa, narodu. Co powie Jaruzelskiemu, nie wiemy, a przed czasem i trudno i niezręcznie byłoby się w to wdawać $^{41}$.

W numerze 55. jest znamienny fragment: „W piątek Ojciec Św. prosto z Belwederu pojechał do kościoła oo. Kapucynów... ${ }^{42}$ ". Zawarta jest w nim informacja, że Papież był w Belwederze, ale redakcja nie napisała, że właśnie tam odbyło się spotkanie Papieża z Wojciechem Jaruzelskim. O jeszcze jednym spotkaniu z Jaruzelskim wspomniano na ostatniej stronie numeru. W prawym dolnym rogu, wśród informacji o spotkaniach w przededniu powrotu Papieża do Watykanu, znajduje się zdanie: „Na Wawelu spotkał się też z premierem Jaruzelskim”43.

Równie skąpo o spotkaniach z przedstawicielami władz pisano w roku 1987. Jedyna wzmianka o takim spotkaniu znajduje się w numerze 215., gdzie pod koniec artykułu Nowa katecheza znajduje się przywołanie nagłówka z oficjalnej prasy:

Tymczasem partyjna prasa wybija w wielkim tytule na pierwszej stronie „Kulminacyjny moment pierwszego dnia pobytu Jana Pawła II w Polsce — spotkanie z gen. Jaruzelskim na Zamku”. [...] Ale Papież bezbłędnie ucieka z propagandowej pułapki. Gen. Jaruzelski w przemówieniu na Zamku dokładnie powiedział, czego spodziewa się na Westerplatte: potępienia hitlerowskich hord i pochwały pokojowych inicjatyw władz PRL. A Papież znajduje bardziej szczęśliwą formułę, mówi, że każdy ma swoje Termopile i swoje Westerplatte i ani słowa o zachodnich rewizjonistach, ani słowa o planie rozbrojeniowym Jaruzelskiego ${ }^{44}$.

Redakcja „Tygodnika Mazowsze” bardzo powściągliwie relacjonuje spotkania Papieża z przedstawicielami władz państwowych i sporadycznie o nich wspomi-

40 „Solidarność Tygodnik Mazowsze. Fotoaneks Fotograficznej Agencji Solidarność”, nr 4 (8-14.06. 1987), s. 1-4.

${ }^{41}$ J.P., Czekając na Papieża, „Tygodnik Mazowsze” nr 46, 7.04.1983, s. 3.

42 Kronika wizyty, op. cit., s. 1.

${ }^{43}$ Ibidem, s. 4.

${ }^{44}$ W.K., Nowa Katecheza, „Tygodnik Mazowsze”, nr 215, 17.06.1987, s. 4. 
na. Może to wynikać nie tylko z niechęci w stosunku do władz, lecz także z tego, że oficjalne środki przekazu bardzo obszernie relacjonowały te punkty programu pielgrzymki, natomiast w prasie podziemnej skupiano się na wydarzeniach, które w mediach pierwszego obiegu nie mogły zostać przedstawione.

\section{Wymiar artystyczny}

W wymiarze artystycznym opisu papieskich pielgrzymek mieszczą się teksty, w których dominuje funkcja artystyczna. Jeden z nich został opublikowany w numerze 58 ., gdzie na pierwszej kolumnie redakcja umieściła wiersz Barbary Sadowskiej, matki zamordowanego parę miesięcy wcześniej Grzegorza Przemyka, List do Ojca Świętego Jana Pawła $I I^{45}$. O ile sam wiersz ma charakter artystyczny, to warto zwrócić uwage na to, że publikacja spełnia kryteria kontekstu społeczno-politycznego, bo autorka była matką chłopca zakatowanego przez funkcjonariuszy Milicji Obywatelskiej.

\section{Obraz władz}

Na obraz władz składają się działania organów państwa: Milicji Obywatelskiej, Służby Bezpieczeństwa; oficjalnych mediów i propagandy, a także cenzury.

Już w czasie oczekiwania na drugą pielgrzymkę są opisywane przygotowania rządzących. W tekście zatytułowanym Gdy policjant ma podjąć Papieża ${ }^{46}$ autor pisze o tysiącach milicjantów zaangażowanych do pilnowania porządku. Używa przy tym określenia strzec porządku ujętego w cudzysłów, co podważa pierwotne znacznie i sugeruje, że milicjanci mają być wykorzystani do innych celów. Pisze także o cenzorskich wytycznych z Komitetu Centralnego PZPR dla dziennikarzy, aby nie używali określeń „Ojciec Święty” i „Jego Świątobliwość”47. W spomina o ograniczeniach w transmisji telewizyjnej z pielgrzymki:

Telewizja ma w sumie nadać 10 godzin relacji z pobytu Jana Pawła II. Znaczna cześć tego czasu to programy o zasięgu lokalnym, na przykład transmisję z Poznania TV ma nadawać tylko dla Polski Północnej, ale bez Gdańska i Olsztyna ${ }^{48}$.

Autor wspomina także o materiałach dyskredytujących Kościół katolicki, które ukazały się w oficjalnych mediach przed pielgrzymką, oraz o planowanym wykorzystaniu propagandowym wizyty Papieża przez władze. Cały tekst przedstawia negatywny obraz działań organów władz państwowych.

\footnotetext{
${ }^{45}$ B. Sadowska, List do Ojca Świętego Jana Pawła II, „Tygodnik Mazowsze” nr 58, 28.07.1983, s. 1.

46 Gdy policjant ma podjąć Papieża, „Tygodnik Mazowsze” nr 54, 2.06.1983, s. 1.

47 Ibidem.

48 Ibidem.
} 
Zachowanie funkcjonariuszy Milicji Obywatelskiej podczas pielgrzymki jest widoczne we fragmencie mówiącym o powrocie wiernych z mszy, która odbyła się na Stadionie Dziesięciolecia w Warszawie:

Przy zejściu z mostu [Mostu Poniatowskiego - R.W.] od strony Śródmieścia, obsadzonym przez milicję, tłum rozproszył się. Kilkutysięczny pochód dotarł do roku [sic! - R.W.] Tamki i Dobrej, gdzie doszło do interwencji milicji (użyto pałek, kilkadziesiąt osób aresztowano) ${ }^{49}$.

\section{$\mathrm{W}$ „Tygodniku Mazowsze” recenzowano również działania oficjalnej propagandy:}

Ogólnie linię propagandy można scharakteryzować tak: pokazać jak najmniej z pobytu Ojca Świętego, jak najrzadziej oddać Mu głos, dobrze jest coś zacytować pomijając niewygodne fragmenty, jeszcze lepiej opowiedzieć wszystko własnymi słowami ${ }^{50}$.

\section{Omawiano także działania cenzury:}

Wystąpienia Papieża miała w całości drukować tylko prasa katolicka. Jednak w „Tygodniku Powszechnym" nr 56 cenzor tak okaleczył tekst homilii wygłoszonej w warszawskiej katedrze, że redakcja nie zdecydowała się na publikację. Cenzura zdjęła również rozważania z Apelu Jasnogórskiego. W ślad za tym z numeru spadły dosłownie wszystkie wzmianki na temat spotkania Papieża z młodzieżą ${ }^{51}$

Podobnie było w czasie trzeciej pielgrzymki:

$\mathrm{Z}$ dnia na dzień zadanie propagandy stawało się coraz trudniejsze. Wobec zdecydowanej wymowy politycznej słów Papieża utrzymanie obrazu „pielgrzyma pokoju” wymagało zdecydowanych przemilczeń, przekłamań i rozmydlania znaczeń. O przemówieniu w Gdyni PAP poinformował jednym zdaniem: „Wygłosił przemówienie do ludzi morza” homilia na Zaspie została zrelacjonowana jako wypowiedź o treści historyczno-marynistycznej: „Witam i pozdrawiam Gdańsk /.../ gród sprzed 1000 lat, gdzie przybył św. Wojciech / . . / stale tu nad brzegiem Bałtyku otwierał przed nami te perspektywy, jakie ukazuje człowiekowi morze"52.

Przy okazji trzeciej pielgrzymki opisano także działania Służby Bezpieczeństwa, przeprowadzającej rozmowy ostrzegawcze z działaczami „Solidarności”, podczas których radzono im pozostanie w domach na czas wizyty Papieża ${ }^{53}$. Pielgrzymów udających się na msze spotykały utrudnienia w drodze. Są one opisane w artykule Droga do Gdańska ${ }^{54}$, który jest relacją z wyjazdu czterech autokarów warszawskich duszpasterstw ludzi pracy na mszę świętą do Gdańska. Uczestnicy wyjazdu byli nękani kontrolami drogowymi:

W okolicach Nidzicy znów kontrola, wśród funkcjonariuszy ci sami, co w Zakroczymiu, czepiają się, że brakuje młotka do rozbijania szyby awaryjnego wyjścia, apteczka jest niepełna, nie ma kluczyków do liczników kilometrów (rutynowo przechowywanych w bazie). Przy okazji dokładny „kipisz” pasażerów i wozów [... $]^{55}$.

${ }^{49}$ Kronika wizyty, op. cit. s. 1.

${ }^{50}$ Mass media. Propaganda i cenzura, „Tygodnik Mazowsze” nr 56, 30.06.1983, s. 3.

${ }^{51}$ Ibidem.

52 FF, Papamobil czyli propaganda o pielgrzymce Papieża, „Tygodnik Mazowsze” nr 216,

1.07.1987, s. 3.

53 SB po swojemu..., „Tygodnik Mazowsze” nr 214, 3.06.1987, s. 1.

${ }^{54}$ Droga do Gdańska, „Tygodnik Mazowsze” nr 215, 17.06.1987, s. 4.

55 Ibidem. 
Wszystkie opisy działań służb państwowych mają negatywny kontekst: milicja bije i aresztuje ludzi, oficjalna propaganda manipuluje, cenzura zabrania publikacji wystąpień papieskich, Służba Bezpieczeństwa nęka pielgrzymów udających się na spotkanie z Papieżem.

\section{Podsumowanie}

Analiza tekstów odnoszących się do obu pielgrzymek pozwala określić różnice w ich opisach. W przypadku drugiej pielgrzymki widać entuzjazm i radość ze spotkania z Papieżem. Z kolei w roku 1987 pojawiają się akcenty krytyczne: zniechęcenie i brak pozytywnych oczekiwań związanych z trzecią wizytą Papieża. Jest to znacząca różnica w opisach tych dwóch wydarzeń.

Pielgrzymki papieskie w przekazie „Tygodnika Mazowsze” są ważnymi medialnymi i wielowymiarowymi wydarzeniami. Na konstrukt pielgrzymek wpływają aspekty: religijny, społeczno-polityczny, a nawet artystyczny, co wydaje się raczej rzadkie w prasie informacyjno-publicystycznej. Spośród nich najważniejszy wydaje się wymiar społeczno-polityczny. To właśnie kwestie związane z aktualną sytuacją społeczną i polityczną w Polsce dominują w tekstach odnoszących się do pielgrzymek. Redaktorzy tygodnika nawet w homiliach papieskich zwracają uwagę na słowa odnoszące się do braku poszanowania praw człowieka przez władze, represji, ograniczenia swobody zrzeszania czy swobody wypowiedzi. Z powyższym koresponduje obraz władz, których działania są przedstawiane jedynie w negatywnym kontekście. Powstaje w ten sposób bardzo czytelny dychotomiczny, czarno-biały obraz świata. Po jednej stronie znajduje się poddane opresji społeczeństwo, którego głosem jest Jan Paweł II, po drugiej zaś — zła, represyjna władza.

Wydaje się, że na obraz pielgrzymek w „Tygodniku Mazowsze” wpływają zaangażowanie polityczne redakcji oraz to, że analizowane czasopismo wychodziło w drugim obiegu wydawniczym, który ze swej istoty stał w opozycji do władzy i mediów oficjalnych. W związku z tym w opisach pielgrzymek realizowane są swego rodzaju fundamentalne założenia tego segmentu mediów: przedstawiają one głównie to, co jest dla władzy niewygodne, przez władzę pomijane i skierowane przeciwko niej. $\mathrm{W}$ tak realizowanym konstrukcie sama władza została odmalowana w negatywnym świetle.

Pielgrzymki papieskie są wydarzeniami wyjątkowymi. Te, które odbywał Jan Paweł II do Polski, były wyjątkowe także dlatego, że Papież przybywał do kraju, z którego pochodził, co więcej, do kraju, w którym kilkanaście miesięcy wcześniej wprowadzono stan wojenny i represjonowano znaczną część społeczeństwa. Teksty w „Tygodniku Mazowsze” są specyficznym zapisem tamtego czasu. Zapisem wyjątkowym, bo „z podziemia”, z punktu widzenia ludzi zmuszonych do działań nielegalnych, ludzi walczących o swobody obywatelskie. 


\section{Bibliografia}

Dayan D., Katz E. (2008): Wydarzenia medialne. Historia transmitowana na żywo, przeł. A. Sawisz, Warszawa.

Głowiński M. (1991): Opis papieskiej podróży, [w:] idem, Nowomowa po polsku, Warszawa, s. 68-88.

Jabłoński S. (2011): Pielgrzymka [hasło w:], Encyklopedia katolicka, red. E. Gigilewicz, Lublin, t. 15, szpalta 480.

Łabędź K. (2019): Opozycja polityczna wobec drugiej pielgrzymki Jana Pawła II do Polski, [w:] Papieskie pielgrzymki w PRL, red. W. Polak, J. Kufel, P. Ruchlewski, Gdańsk, s. 229-243.

Majchrzak G. (2019): Pielgrzymka obaw i nadziei. Solidarność wobec trzeciej pielgrzymki Jana Pawła II do Polski, [w:] Papieskie pielgrzymki w PRL, red. W. Polak, J. Kufel, P. Ruchlewski, Gdańsk, s. 347-359.

Majchrzak G. (2014): „Wyjdźmy mu na spotkanie”. „Solidarnośc” wobec II pielgrzymki Jana Pawła II do Polski, [w:] Pielgrzymka nadziei. II wizyta Jana Pawła II w Ojczyźnie. Materiały pokonferencyjne, Warszawa, s. 91-103.

Olaszek J. (2018): Podziemne dziennikarstwo, Warszawa.

Pielgrzymka Jana Pawła II do Polski. Przemówienia. Dokumentacja (1979): Poznań-Warszawa.

Pisarek W. (1983): Analiza zawartości prasy, Kraków.

Polak W. (2019): Trzy pierwsze pielgrzymki Jana Pawła II do Polski - fakty, refleksje, wspomnienia, [w:] Papieskie pielgrzymki w PRL, red. W. Polak, J. Kufel, P. Ruchlewski, Gdańsk, s. 128-156.

Polak W., Kufel J., Ruchlewski P. (red.) (2019): Papieskie pielgrzymki w PRL, Gdańsk.

Przastek D., Mrowiński P. (2019): Scenografia liturgii. Kontekst społeczno-polityczny ołtarzy papieskich, [w:] Papieskie pielgrzymki w PRL, red. W. Polak, J. Kufel, P. Ruchlewski, Gdańsk, s. 393-418.

Szymczak M. (red.) (1995): Pielgrzymka, [hasło w:] Słownik języka polskiego PWN, Warszawa, t. L-P, s. 623.

www1: Pielgrzymka, [hasło w:] Słownik języka polskiego, red. Witold Doroszewski, https://sjp.pwn.pl/ doroszewski/pielgrzymka;5471527.html (dostęp: 9.02.2021).

www2: Pielgrzymki Jana Pawła II do Ojczyzny, https://domjp2.pl/jan-pawel-ii/pielgrzymki-jana-pawla-ii/ (dostęp: 8.02.2021).

www 3: Szarek J. „Tygodnik Mazowsze”, [hasło w:] https://encysol.pl/es/encyklopedia/hasla-rzeczowe /14636,Tygodnik-Mazowsze.html (dostęp: 10.02.2021).

\section{The media image of John Paul II's pilgrimages to Poland in the 1980s in Tygodnik Mazowsze}

\section{Summary}

The article presents a reconstruction of the media image of two pilgrimages of John Paul II to Poland in the 1980s. Texts from Tygodnik Mazowsze, one of the most important periodicals in the so-called second publishing circuit (underground publishing), were chosen as the source material and magazine content analysis was selected as the method. It allowed for the identification of differences in the descriptions of both pilgrimages. Based on thematic categorization, it was possible to indicate that the media image of papal visits in Tygodnik Mazowsze was mainly influenced by the socio-political context. Descriptions of pilgrimages were part of the black-and-white image of the world.

Keywords: pilgrimage, John Paul II, underground press, Tygodnik Mazowsze, content analysis. 